\title{
Federal Fiscal Policy Since the Employment Act of 1946
}

\author{
Keith M. Carlson
}

$\mathbf{T}$

Het Employment Act of 1946 assigned to the federal government the official responsibility to achieve and maintain a high level of employment. According to the act:

The Congress hereby declares that it is the continuing policy and responsibility of the Federal Govermment to use all practicable mears ... to promote maximum employment, production, and purchasing power,

While the act does not specify how to achieve these goals, monetary and fiscal policy over the past 40 years have evolved into the primary tools of stabilization policy.

The general purpose of this article is to summarize fiscal policy since the Employment Act of 1946. The meaning and significance of fiscal policy are discussed, including some measurement problems associated with fiscal actions. Different measures of fiscal action during periods when the pace of economic activity was significantly above or below trend are examined to determine whether the direction of fiscal actions generally has been consistent with the Employment Act.

\section{THE MEANING OF FISCAL POLICY}

Fiscal policy is the use of federal expenditures and taxes to stabilize the economy. Two aspects of this definition require clarification. First, for the most part,

Keith $M$. Carlson is an assistant vice oresident at the Federal Reserve Bank of St. Louis, James C. Poletti provided research assistance.

For discussion of the evolution of the Employment Act along with its updated version. The Full Employment and Balanced Growth Act of 1978 , see Santoni (1986)

aFrom Public Law 304, quoted in Norton (1985), pp. 79-80 the government does not control directly the dollar amount of expenditures or taxes; instead it controls specific programs and the structure of tax rates. Second, to evaluate fiscal policy, a more specific definition of "economic stabilization" is required

\section{Defining Fiscal Action}

Though Congress is originally responsible for establishing various expenditure programs m.m indeed, it must appropriate funds each year to keep a program in place - the dollar cost of implementing and maintaining such programs depends on economic conditions, including movements in the general level of prices. Similarly, though Congress legislates tax rates, the performance of the economy in conjunction with these rates determines the dollar amount of tax receipts. Once a tax structure is established, receipts are forthcoming in a particular year without any further action by the government.

The 1962 Economic Report of the President summarized the government's control problem diagrammatically. In figure 1 , panel $A$, an expenditure program is shown as a downward-sloping time, $E_{x}$, reflecting primarily the decline in unemployment benefits as real GNP increases. In combination with a given structure of tax rates the line $T_{10}$, the surplus or deficit $\left(S_{13}\right)$ is also drawn as a function of the level of GNP in the bottom portion of panel $A$. A fiscal action, in this case an increase in spending programs, is shown as a shift of

\footnotetext{
${ }^{3}$ Council of Economic Advisers (1962), pp. 77-84. Using real GNP on the horizontal axis implies that the expenditure and tax lines are drawn for a given price level. To avoid complicating the analysis, price level problems are not considered explicitly here. For detailed discussion of such problems, see Carison (1983).
} 
Figure 1

An Illustration of Fiscal Actions

(A)

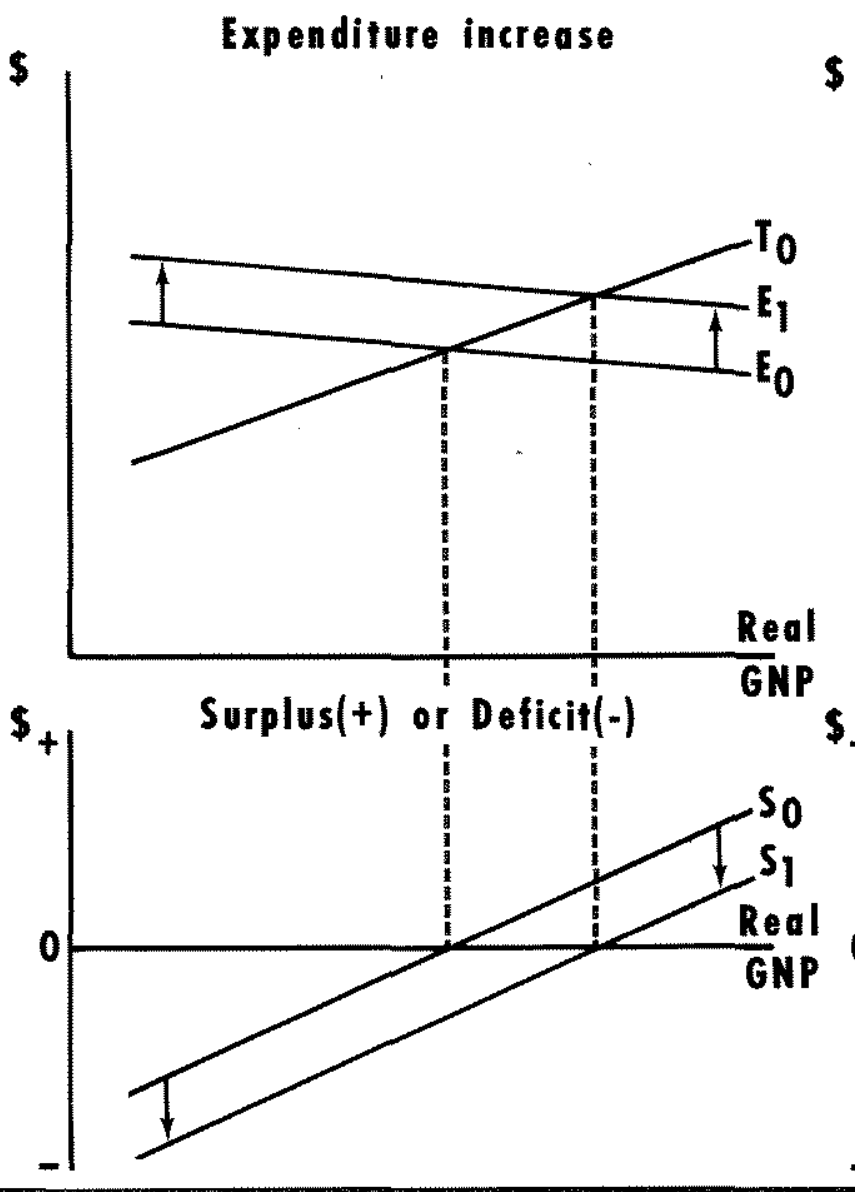

(B)

Tax increase

$\$$
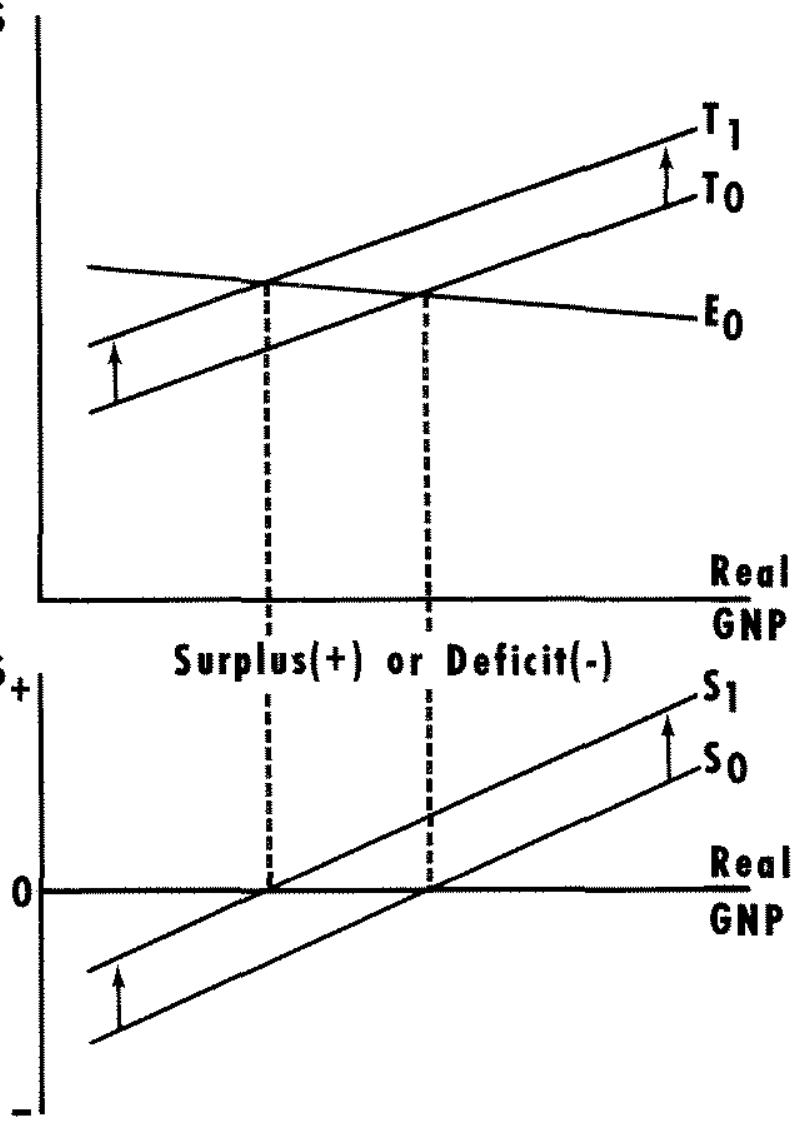

the expenditure line to $\mathrm{E}_{x_{1}}$, which also shifts the surplus/deficit line. But because the new level of expenditures is now greater for each level of GNP, the surplus is less (or the deficit is more) at each GNP level.

Similarly, the affects of a tax action are shown in panel $B$ of figure 1. A given structure of tax rates is shown as an upward-sloping line, $T_{0}$, indicating that taxes increase with the level of GNP. An increase in tax rates will shift the surplus/deficit line upward, to $S_{1}$. This shift represents the effect of legislated or administered fiscal actions.

\section{Defining Economic Stabilization}

The second clarification concerns the meaning of the term "stabilizing the economy." While the wording of the Employment Act can serve as a guide, it is not very specific. In particular, the word "maximum" is subject to a variety of interpretations. A working interpretation has evolved over the years, since one was never clearly delineated in the late 1940 s and 1950s. A considerable amount of controversy revolves around the specific goals associated with economic stability.

In theory, the objective of fiscal policy can be defined quite clearly. If the economy is subject to fluctuations, fiscal policy should be used to dampen those fluctuations. To illustrate, see figure 2 . The solid line summarizes a cyclical pattern for GNP around an upward trend. A policy of economic stabilization, as shown by the dashed line, dampens the fluctuations. Generally, this would be achieved by taking restrictive action when GNP is above trend and stimulative action when it is below. Doing this at the right time and in the right dosage is, of course, difficult in practice. None- 
Figure 2

\section{The Meaning of Economic Stabilization}

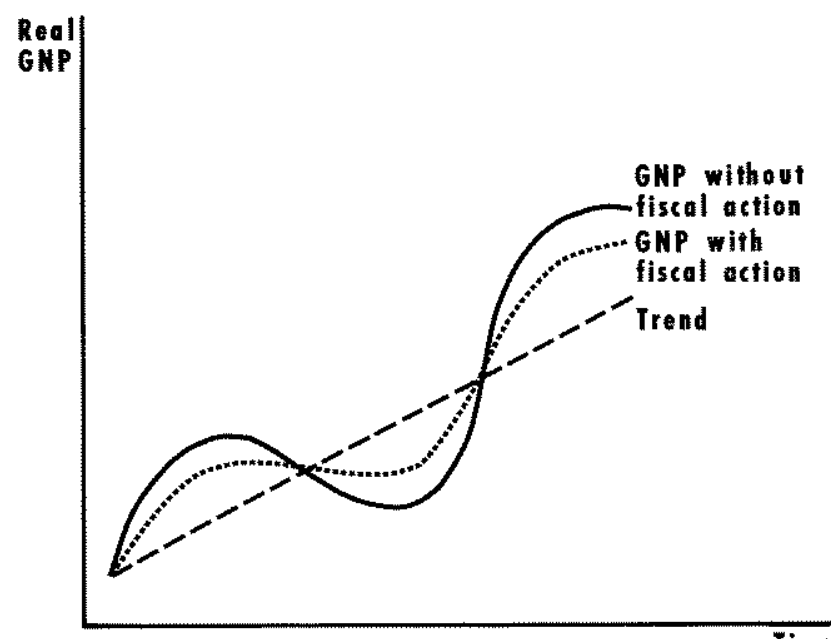

Time

theless, this concept does provide a framework for assessing the success or failure of past actions, which, in turn, might be useful as a guide to formulating future actions.

\section{THE MEASUREMENT OF FISCAL ACTIONS}

There has been continuing controversy over the proper role, if any, for fiscal policy in the U.S. economy since the Employment Act of 1946 was passed. Many issues remain unsettled. Accompanying the debate about the theory of fiscal policy have been significant changes in the way fiscal actions are measured.

\section{Evolution of Budget Data}

When the Employment Act of 1946 was passed, about the only data readily available on the federal budget were the figures released in the budget document itself. These figures were for fiscal years for the administrative budget and excluded the transactions of trust funds, for example, social security. The development of the national income accounts budget in the 1950 s resulted in the avalability of quarterly data. Later, the transactions of the trust funds were com

${ }^{4}$ For an exhaustive survey of the theory of fiscal policy, see Brunner (1986). bined with the administrative budget, producing the consolidated cash budget. ${ }^{5}$

Currently, the unified budget, which succeeded the consolidated cash budget, serves as the primary budget measure used by the government in its fiscal planning. The federal sector of the national income and product accounts, sometimes called the national income accounts budget, is considered a more useful measure for economic analysis, however (see insert).

\section{Full-Employment Budget Concept}

One of the most important innovations in measuring fiscal actions occurred in the 1960 s when the full employment budget was developed as a part of the Economic Report of the President. The fullemployment budget is not really a budget at all: it is an analytical measure that adjusts federal expenditures and receipts in the national income accounts to account for the feedback effects of economic activity. One of its main features is to draw the distinction between active and passive deficits (or surpluses). Active deficits (surpluses) result from policy actions, that is, they reflect legislated or administered changes in expenditures or tax rates. Passive deficits tsur. pluses reflect the influence of economic activity on the deficit, given the spending programs and the tax structure in place. This distinction is shown in figure 3 , which reproduces panel $A$ in figure 1 except that the full-employment level of GNP is now a dashed vertical line. An active deficit (in this case, a smaller surplus) is shown as a movement from $A$ to $B$. A movement from $A$ to $C$ can be described as a passive deficit lagain a smaller surplust.

The full-employment budget was renamed the high-employment budget in the late 1960 s and later changed to the cyclically adjusted budget in $1983 .^{7}$ Despite these changes, its purpose is unchanged: to adjust actual expenditures and receipts for the infuence of changing economic conditions.

\section{Other Measures}

In recent years, other measures of fiscal action have been introduced; most of them are refinements of existing measures. For example, with the recent growth in the importance of interest cost, and its role in eventually eradicating deficits, James Tobin has

sPresident's Commission on Budget Concepts (1967).

Eouncil of Economic Advisers (1962), and Carson (1967).

${ }^{7}$ de Leeuw and Holloway (1983). 


\section{The Budget and Federal Sector of the National Ineome and Product Aceounts}

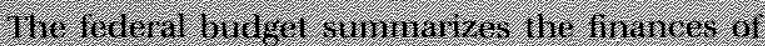

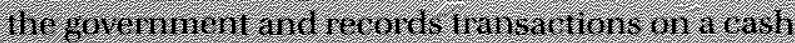

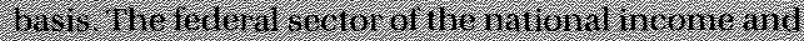

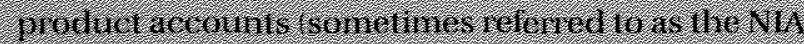

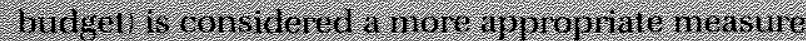

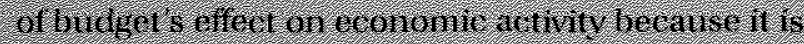

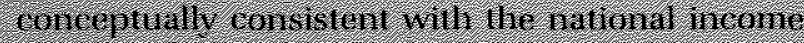

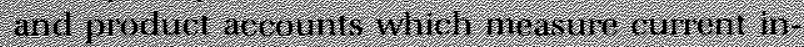

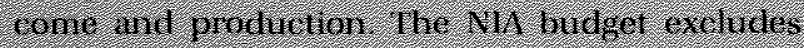

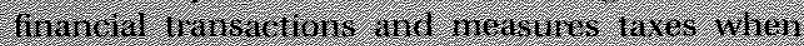

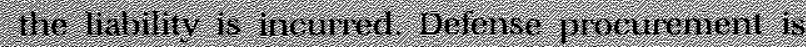

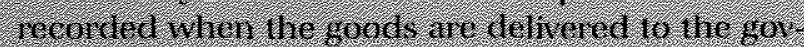

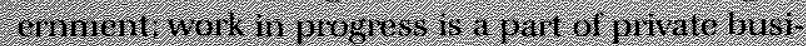

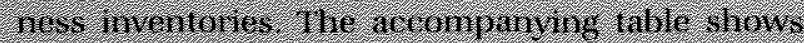

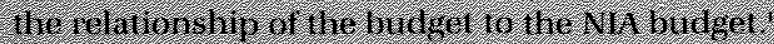

For Hither tiscussion sed budget of the bnied States Gover

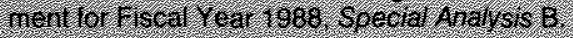

\section{Relationship of Budgets for Fiscal 1986 (billions of dollars)}

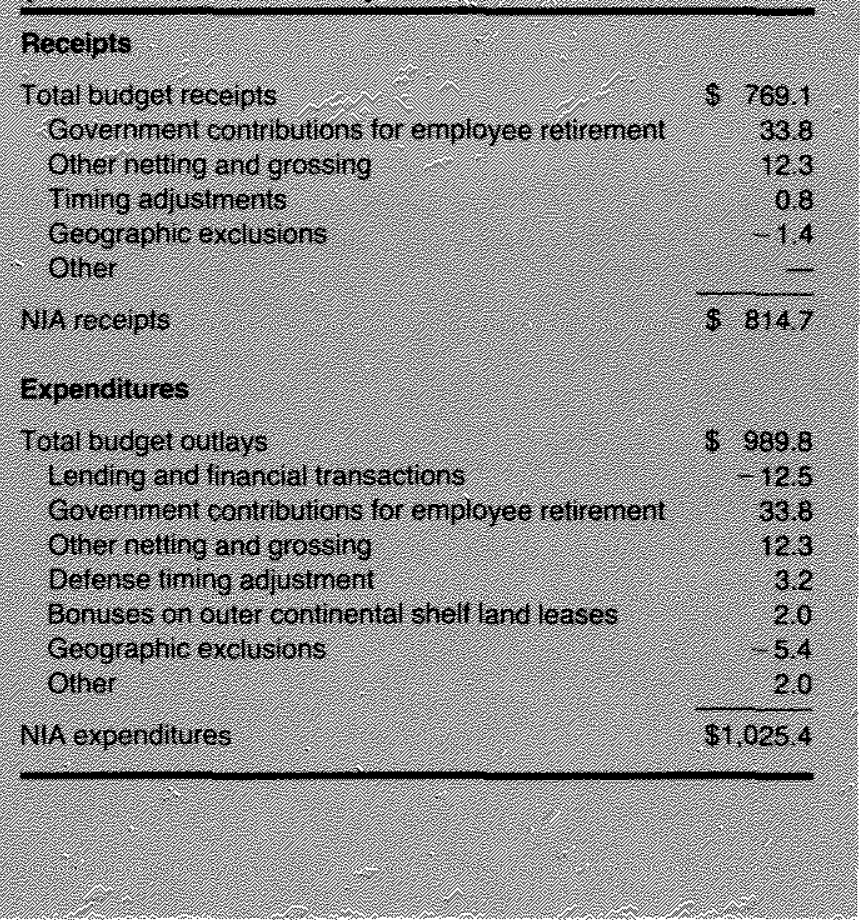

developed the notion of primary surplus or deficit. ${ }^{*}$ This measure is simply the surplus or deficit minus interest payments to the public and Federal Reserve payments to the Treasury. This measure can be calculated on a cyclically adjusted basis as well.

Another measure receiving recent publicity has been developed by Robert Eisner.' His measure, which can be derived for a variety of budget measures, is adjusted for inflation. This means adjusting the deficit for changes in the value of government debt outstanding due to inflation.

\section{ECONOMIC PERFORMANCE AND FISCAL POLICY: AN OVERVIEW}

While several fiscal policy measures have been developed over the years, the cyclically adjusted budget approach is used here to assess the direction of fiscal

${ }^{8}$ Tobin (1984).

FEisner (1986). actions in light of the Employment Act's objectives. This approach attempts to measure the active deficit directly; thus, it represents one measure of "discretionary" fiscal action. Several other variants of the cyclically adjusted budget also are examined.

To assess fiscal policy actions, one must discuss and analyze them in an economic context." The background for this assessment is shown in chart 1 , which summarizes economic and budget data with reference to the ratio of GNP to its trend value." The vertical

${ }^{10}$ For detalled summartes of fiscal policy, see Holmans (1962), Lewis (1962), Stein (1969), Eisner (1986) and Pechman (1987).

1:The trend value is calculated following procedures outlined in de Leeuw and Holloway (1983). Since the Department of Commerce does not attempt to cyclically adjust the price level, the ratio could be interpreted in terms of nominal GNP. That is,

$$
\begin{gathered}
\frac{\text { actuat real GNP }}{\text { trend real GNP }}=\frac{\text { actual real GNP } \times P}{\text { trend real GNP } \times P} \\
\frac{\text { actual nominal GNP }}{\text { trend nominal GNP }}
\end{gathered}
$$




\section{Figure 3 \\ Full-Employment Budget}

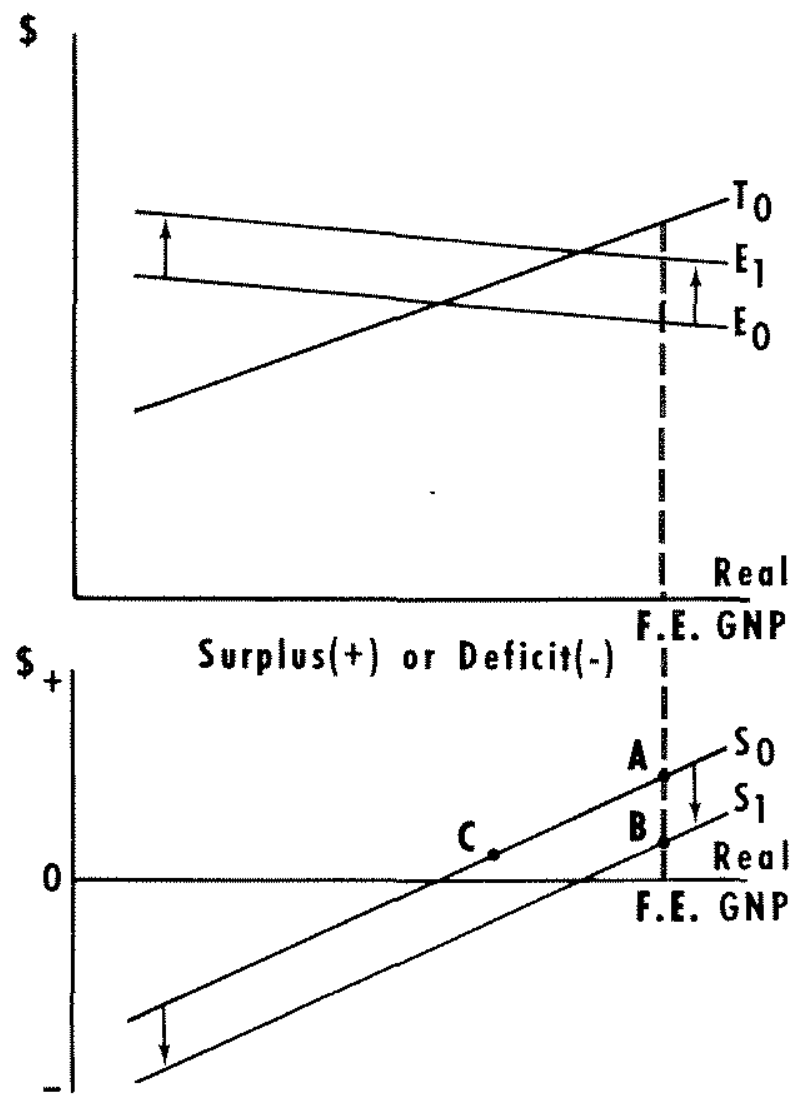

lines represent periods when GNP was persistently above or below trend, or when it was moving along trend. The choice of periods using trend GNP as a point of reference follows the interpretation of figure 2 and differs from procedures followed by the National Bureau of Economic Research where reference points are based on whether economic activity is rising or falling.:

The top tier of chart 1 summarizes U.S. economic performance as measured by the ratio of GNP to its trend value from 1947 through 1986. U.S. economic performance in the late 1940 s and early 1950 s was

\footnotetext{
2a Note that the focus is on real GNP movements, thus deemphasizing the problems of inflation. Generally, periods when GNP is above trend are also periods of inflation. The "stagflation" case is not addressed explicitly; the assumption is made that the Employment Act places priority on real economic performance during such times.
}

quite volatile, reflecting, in part, the influence of wars and their aftermath. During the second half of the 1950 s and the early 1960s, economic performance fluctuated relatively close to trend. The second half of the 1960 s again reflected wartime conditions. Finally, economic performance in the 1970 s and 1980 s showed considerable fluctuation around trend, even though there were no major wars.

The bottom tier of the chart summanizes fiscal actions as meastred by the surplus or deficit in the cyclically adjusted budget. To adjust the level of the surplus or deficit for the size of the economy, we divide by the trend value of GNP in current dollars. The resulting measure is quite volatile on a quarterly basis.

This measure of fiscal action was well in surplus in the late 1940s. The sharp movement from suplus to deficit in the early 1950 s followed by the movements back to surplus reflected the Korean War and its aftermath. During the mid-1950s, this budget measure stayed in surplus until 1958 before dipping temporarily into deficit; it bounced back into surplus in 1960.

The period from 1960 to 1968 was one of considerable volatility around a downward trend. Except for one quarter in 1963 , this budget was in deficit, increasingly so toward the end of the period when defense spending accelerated during the Vietnam War. By late 1968, however, there was a sharp movement toward a smaller deficit after a belated tax increase to finance the war. The smaller deficit persisted for the most part until 1975, reflecting mainly the phasing out of the Vietnam War."'

The second half of the 1970 s showed a shift toward a larger deficit, highlighted by an anti-recession tax cut in 1975. Following this tax cut, the deficit remained at about 2 percent of trend GNP through 1981. After 1981 , however, the deficit showed a sharp downward movement that genemally persisted through 1986. This drop was associated with accelerated expenditure growth and the Economic Recovery Tax Act of 1981, which cut individual income taxes by 25 percent and accelerated depreciation allowances for corporations. Despite some rescinding of these provisions by the Tax Equity and Fiscal Responsibility Act of 1982, the cyclically adjusted deficit fell below 5 percent of trend GNP by 1985-86. ${ }^{13}$ For a review of the sources of change in the federal deficit, see
Holloway and wakefield (1985). 


\section{Chart 1 \\ GNP and Federal Fiscal Actions Relative to Trend GNP}

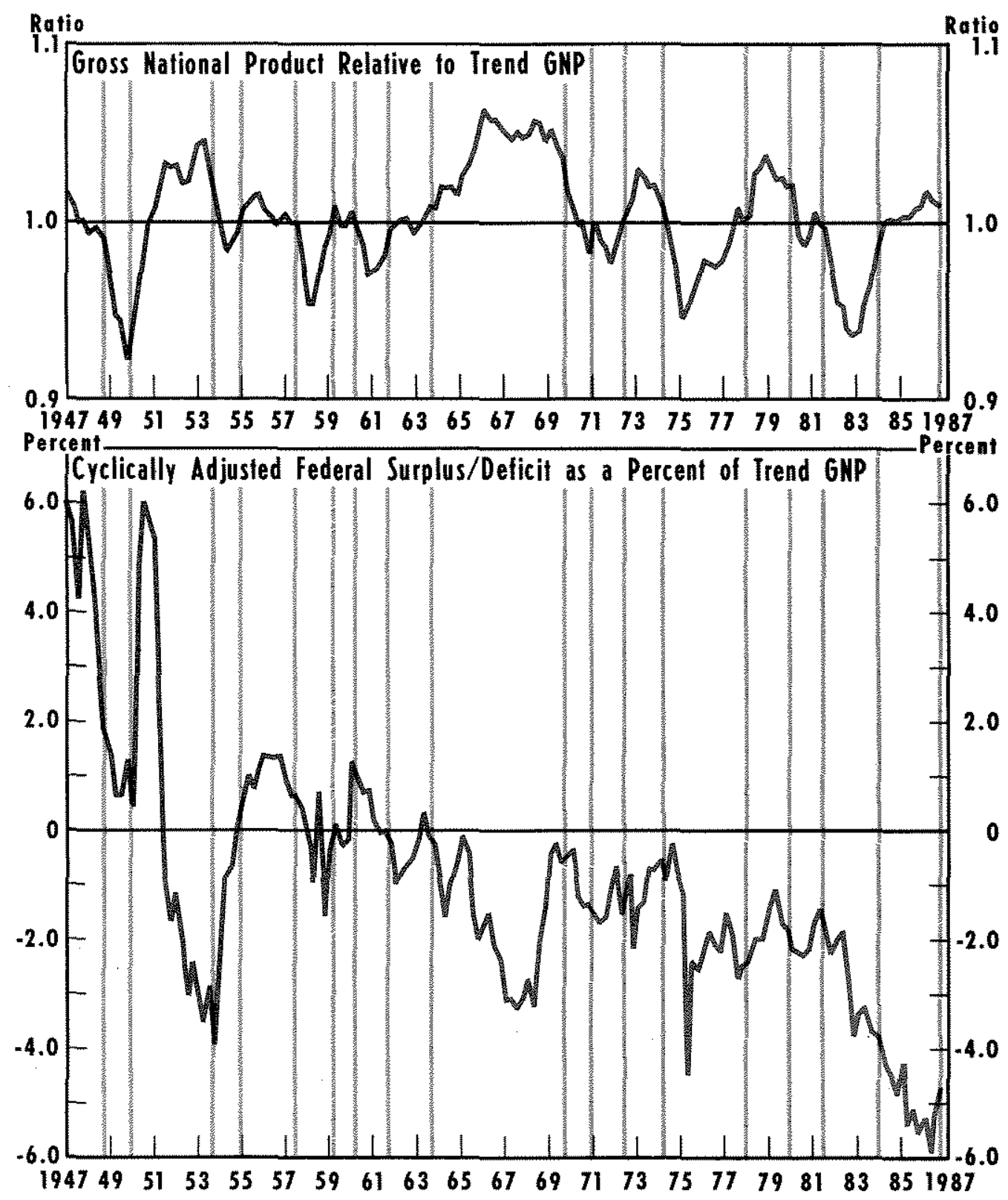

\section{AN ANALYSIS OF FTSCAL ACTIONS: $1947-86$}

To analyze whether fiscal policy has been conducted in a manner consistent with the Employment Act, the last 40 years was divided into 18 periods, as shown in chart 1 . In the presumed spirit of the Employment Act, assessments of whether "easier" of "tighter" fiscal actions were called for were made as follows: periods when GNP was persistently below trend were viewed as calling for easier fiscal actions; periods when GNP was above trend were judged to 
call for tighter fiscal actions. A growth of GNP along trend suggests that fiscal actions were satisfactory.

The subperiods are summarized on the left side of tables 1-3; the "description" column in these tables summarizes the relation of GNP to trend during these periods. "Required policy" follows from our analysis above. In some cases, because GNP was coming off such a high level, the early stages of recession were sometimes lumped in with "expansion above trend" (see I/1951-IV/1953 and II/1959-II/1960). Two other recessions were not noted separately: $1969-70$ and 1980 ; the $1969-70$ recession appears mild in retrospect and the 1980 recession was so short, as was the ensuing recovery, that it was not treated separately. In some periods, where it is not obvious what the "required policy" was, such cases are labeled "unknown."

Tax policy and expenditure policy are examined separately. The tax system is, in a sense, self perpetuating. Once a tax structure is put in place, the economic system will generate a stream of tax receipts without further "discretionary action." Expenditure policy, on the other hand, is not as automatic. For the most part, to implement new programs or continue existing ones, some congressional action is required. After examining the tax and expenditure policies separately, the two are combined to assess overall fiscal policy.

\section{Federal Tax Policy}

Table 1 summarizes tax policy over the 1947-86 period with the annual rate of change of cyclically adjusted receipts. This change is termed "restrictive" of "stimulative," depending on whether its growth rate was larger or smaller than that of trend GNP in curent dollars. Using cyclically adjusted receipts as a measure of discretionary action implies that they were moving as the policymakers wanted them to. For example, if such receipts were growing significantly faster than trend GNP, we assume that policymakers were content with that outcome."

According to table 1, over the entire 40-year period tax policy was restrictive in 12 of the 18 periods, although in some cases marginally so (as shown with

\footnotetext{
14 The Commerce Department also calculates another measure, which purports to be a measure of discretionary tax action. It is derived trom total cyclically adjusted receipts by subtracting an estimate of the automatic effect of inflation on such receipts (See Holloway (1984)). The Commerce Department calls this residual "receipts change due to discretionary and other factors." Use of this alternative measure did not alter the conclusions.
}

question marks in table 1 ). This apparently reflected the progressive nature of the tax system and the contimuing increases in social security taxes, even with the multitude of tax actions legislated throughout the periods (see appendix).

To determine the tax policy response to economic conditions, we focus on those periods when GNP was persistently above or below trend. For the nine periods in which GNP was below trend - mainly recessions and recoveries - tax policy was appropriately stimulative only three times: 11/1960-IV/1961, II/1974-I/1978 and III/1981-w/1984.

GNP was persistently above trend in only foum periods, two of these during wartime. The table shows that tax policy was restrictive in three of the four cases. The two wartime periods however, require special mention. During the Korean War, corporate, individual and excise taxes were raised very quickly after the outbreak of hostilities. As a result, most of the revenue effect occurred in the IV/1948-1/1951 period while the economy was still recovering from the $1948-49$ recession. In the I/1951-IV/1953 period, on the other hand, revenues declined in the latter part of the period because some wartime taxes were allowed to expire.

The Vietnam War was handled much differently. In the early part of IV/1963- $/$ V/1969, most tax actions were stimulative rather than restrictive. Not until 1968 and 1969, long after the war had accelerated, were taxes increased. Because of the 10 percent surcharge on corporate and individual income taxes in 1968, tax policy during the IV/1963-IV/1969 period is shown as restrictive, even though it was stimulative during the early part of this period.

In summary, tax policy often has not been conducted in a manner consistent with the Employment Act. Tax actions that were taken were usually overwhelmed by other considerations, namely, financing wars and the social security system. The record has improved, however, in the 1970 s and 1980s. Major tax cuts were implemented during the $1973-75$ recession and before the 1981-82 fecession; during the 1972-74 and 1978-80 periods of excess demand, taxes in creased faster than GNP.

\section{Federal Expenditure Polley}

Table 2 summarizes federal expenditure policy for the same periods as described in table 1 . The measure of expenditure policy is total cyclically adjusted expenditures; the reason underlying the use of this as a 


\section{Table 1}

\section{Federal Tax Actions}

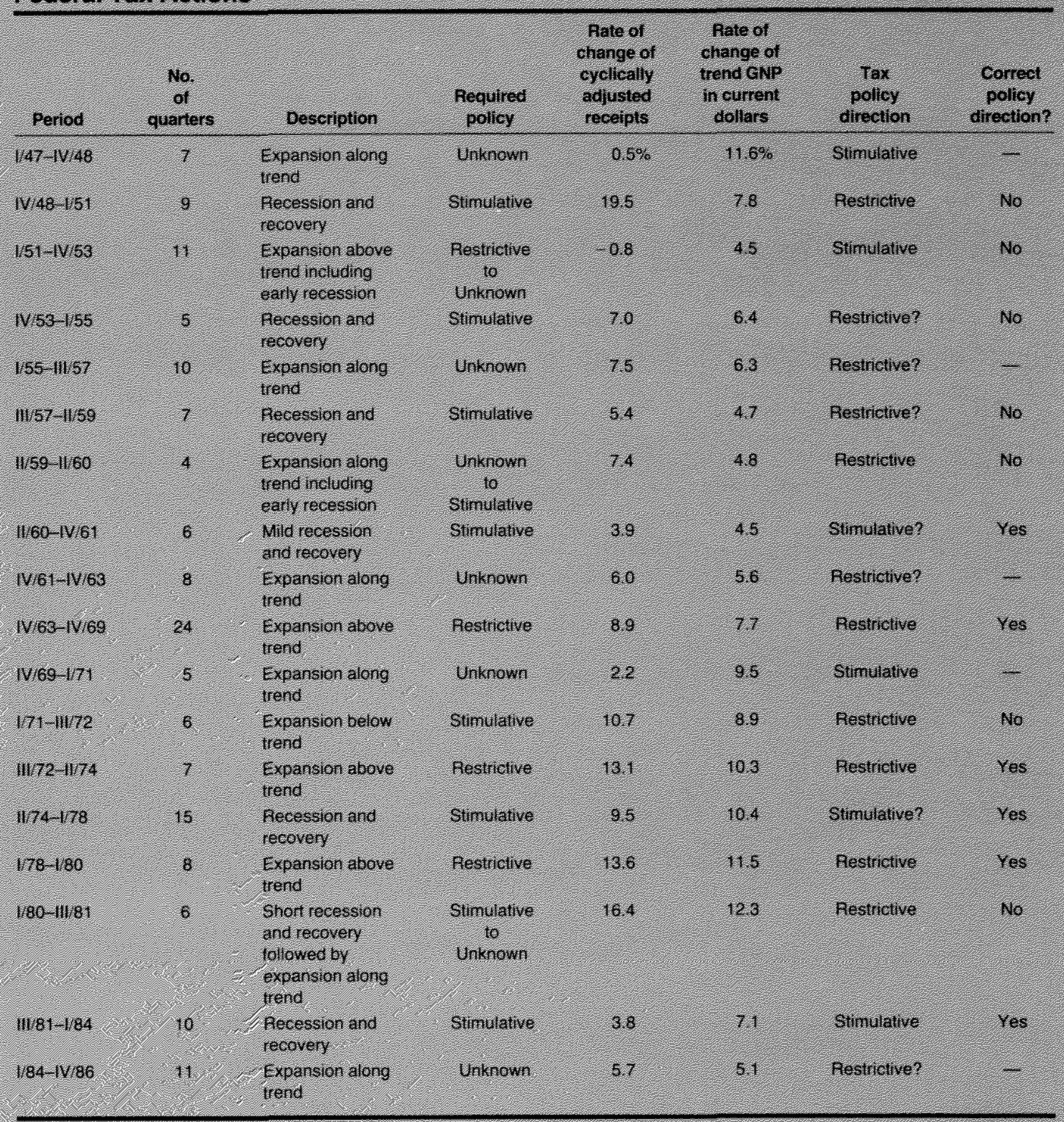




\section{Table 2}

\section{Federal Expenditure Actions}

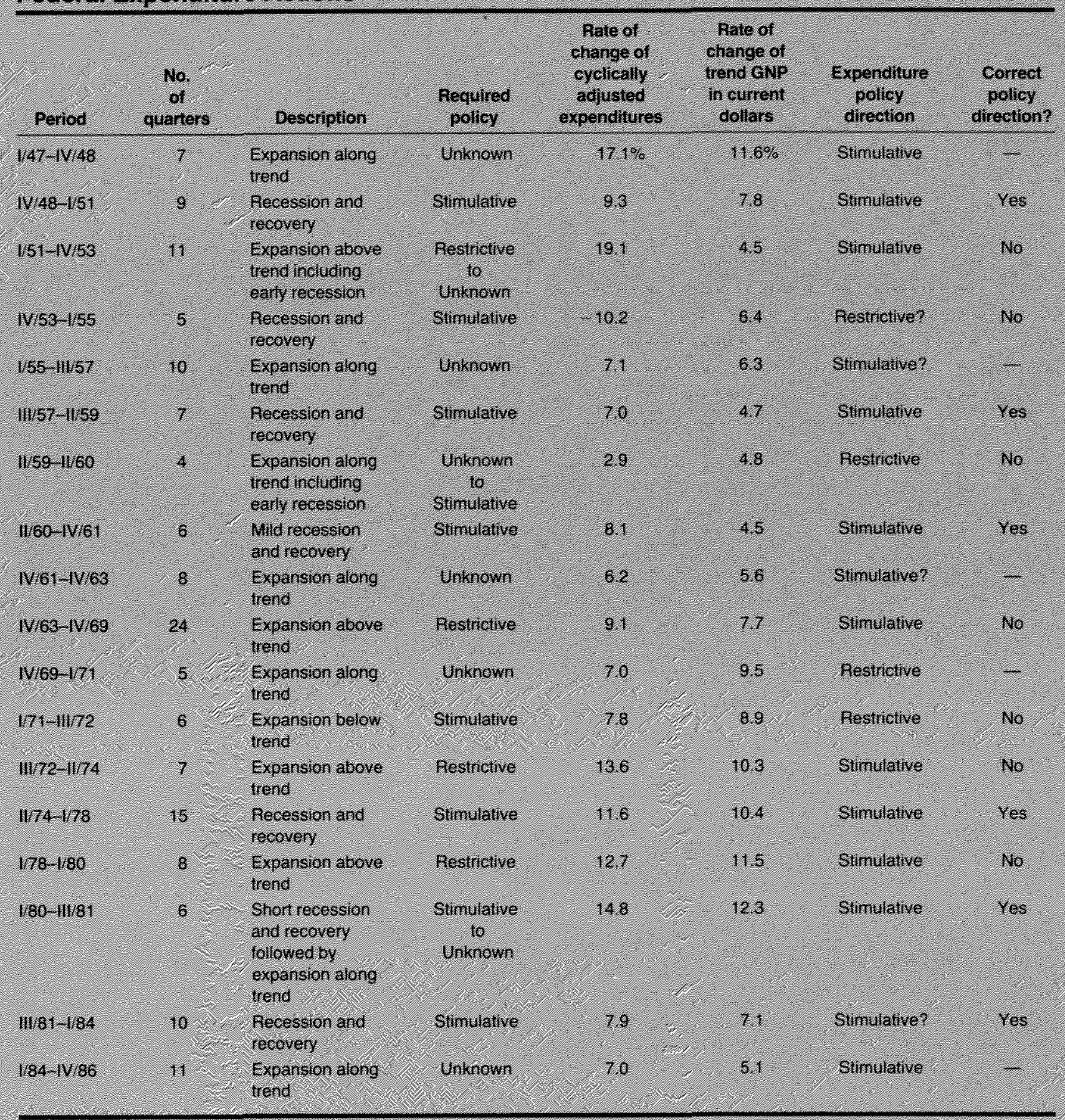


discretionary variable parallels that for cyclically adjusted receipts.:

To determine whether expenditures were stimulative or restrictive, we compare them with trend GNP. Like cyclically adjusted receipts in table 1, we compare total expenditures with trend GNP in current dollars. According to this measure, expenditure actions were stimulative in fourteen of the eighteen periods. The overall 40 year period provides a mixed assessment of expenditure policy. There were nine periods when economic conditions called for stimulative policy. Ex* penditure policy was stimulative in six of those periods. As noted earlier, total expenditures grew faster than trend GNP throughout the entire period. Thus, it is not surprising that expenditure policy just happens to have moved in the appropriate direction more often than not when economic conditions called for policy in a stimulative direction. To refer to such results as an example of success perhaps overrates them.

There were four periods of high demand, when a restrictive policy would have been appropriate; in each case, however, expenditure policy was stimulative. Two of these periods encompassed the buildup for the Korean and Vietnam wars.

On net, like tax policy, federal expenditure policy has not been consistent generally with the Employment Act. During periods of recession and recovery, it was stimulative only two-thirds of the time. During periods of excess demand, it was always stimulative; two of these periods, however, were associated with wars.

\section{Total Fiscal Policy}

As a final step in assessing whether fiscal policy has been conducted consistent with the spirit of the Employment Act, we examine measures of total fiscal policy. An overall measure is derived from tables 1 and 2 and summarized in table 3 . It is the dollar change in expenditures minus the dolar change in receipts, converted to an annual rate, and divided by the aver age of trend GNP (in current dollars) over the relevant subperiod. If this ratio was positive, policy on net was stimulative over the period. If it was negative, policy was restrictive.

\footnotetext{
15The Commerce Department also calculates a direct measure of discretionary expenditure. Reflecting the effect of cost-of-living escafator clauses, it is obtained by subtracting an automatic inflation effect on federal programs from cyclically adjusted expenditures. Use of this measure did not alter the overall conctusions about expenditure policy.
}

In only four of the 12 nonneutral cases did the measure of total fiscal policy move in the right direction. These were recession and recovery pexiods after 1955. When GNP was above trend, the quantitative measures indicated stimulus in each case, although the size of the net stimulus usually was very small. Analysis of this summary measure suggests that fiscal actions generally have moved in a direction opposite to that which would be consistent with the Employment Act.

\section{SUMMARY}

The Employment Act of 1946 designated a role for the federal govemment in stabilizing the level of economic activity. Economists, in general, interpret this to mean that monetary and fiscal actions should be used for that purpose. This article summarizes the general movement of fiscal policy since the 1946 act.

After reviewing the meaning and measurement of fiscal policy, fiscal actions were summarized over the 1947-86 period. This was done by dividing the 40-year period into subperiods depending on the relation of GNP to its trend value. Various measures of fiscal action then were examined to determine if such actions were consistent with the spirit of the Employment Act, focusing on the direction of fiscal response to economic conditions, not on the impact of fiscal actions on the economy.

Although various measures of fiscal actions occasionally offered different conclusions, some tentative general conclusions emerged. Fiscal actions during periods of recession and recovery were usually stimulative, although this assertion is somewhat sensitive to the measure of fiscal action chosen. During periods of high demand and inflation, fiscal actions tended to be inappropriate mainly because these were wartime periods

Overall, it is impossible to determine accurately whether the Employment Act has succeeded or failed in stabilizing the economy. To do so requires an assessment of other policies, and perhaps the inherent stability of private actions, as contributors to the economic stability and progress of the United States over the past 40 years.

\section{REFERENCES}

Brunner, Karl. "Fiscal Policy in Macro Theory: A Survey and Evaluation," in R. W. Hafer, ed., The Monetary versus Fiscal Policy Debate (Rowman and Allenheld, 1986), pp, 33-116. 


\section{Table 3}

\section{Federal Fiscal Policy: Summary Indicators (dollar amounts in billions)}

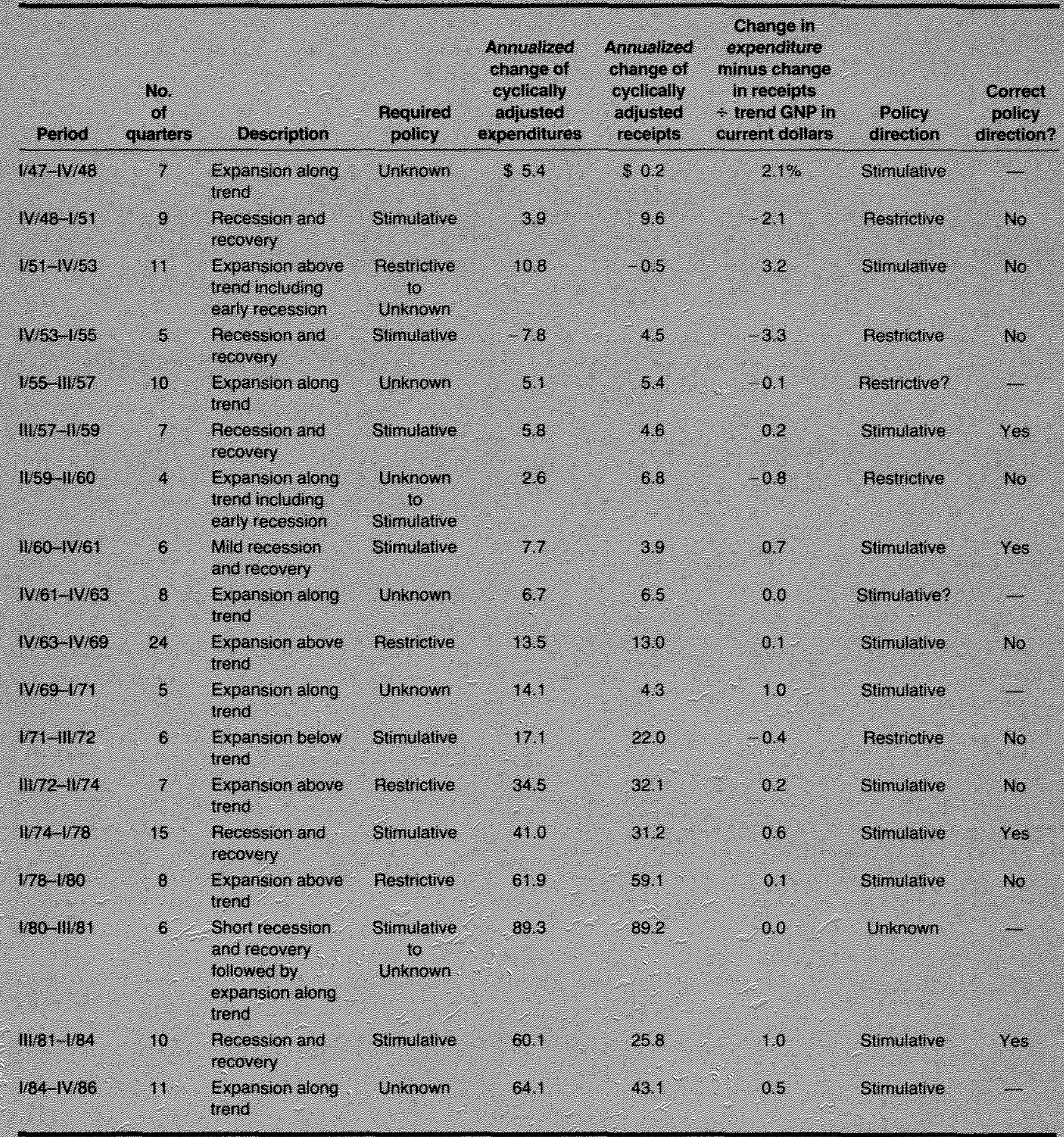


Carlson, Keith M. "Estimates of the High-Employment Budget: 1947-67," this Review (June 1967), pp. 6-14.

. "The Critical Role of Economic Assumptions in the Evaluation of Federal Budget Programs," this Review (October 1983), pp. 5-14.

Council of Economic Advisers. Economic Report of the President (U.S. Government Printing Office, 1962).

de Leeuw, Frank, and Thomas M. Holloway. "Cyclical Adjustment of the Federal Budget and Federal Debt," Survey of Current Business (December 1983), pp. 25-40.

Eisner, Robert. How Real is the Federal Deficht? (The Free Press, $1986)$.

Holmans, A. E. United States Fiscal Policy: 1945-59 (Oxford University Press, 1962).

Holloway, Thomas M. "The Economy and the Federal Budget: Guides to the Automatic Effects," Survey of Current Business (July 1984), pp. 102-05.

Holloway, Thomas M., and Joseph C. Wakefield, "Sources of
Change in the Federal Government Deficit, 1970-86," Survey of Current Business (May 1985), pp, 25-32.

Lewis, Wilfred Jr. Federal Fiscal Policy in the Postwar Recessions (The Brookings Institution, 1962).

Norton, Mugh S. The Quest for Economic Stabitity: Roosevelt to Reagan (University of South Carolina Press, 1985).

Pechman, Joseph A. Federal Tax Policy, 5th ed. (The Brookings Institution: 1987).

President's Commission on Budget Concepts. Staff Papers and Other Materials Revised by the President's Commission (GPO, October 1967).

Santoni, G. J. "The Employment Act of 1946: Some History Notes," this Review (November 1986), pp. 5-16.

Stein, Herbert. The Fiscal Fevolution (University of Chicago Press, 1969)

Tobin, James. "Budget Deficits, Federal Debt, and Inftation," in Albert T. Sommers, ed., Reconstructing the Federal Budget (Praeger Publishers, 1984), pp. 130-49 


\section{Appendix Chronology of Major Federal Tax Actions: 1948-86}

Listed below are the major tax actions affecting federal receipts from 1948 through 1986. The list is not exhaustive but does include the major tax actions. For greater detail, see the following:

The Annual Report of the Secretary of Treasury,

Budget of the United States Government,

Survey of Current Business,

Joseph A. Pechman, Federal Tax Policy, 5th ed., The Brookings Institution, 1987,

Congress and the Nation /Congressional Quarterly, Inc.).

1948 Revenue Act of 1948 lenacted 4-2-48 over president's veto: individual income tax rates reduced, standard deduction increased, exemptions raised and income splitting allowed; effective for calendar 1948 with reduced withholding beginning 5-1-48.

1950 OASDI tax rate raised from 2.0 percent to 3.0 percent.

Revenue Act of 1950 (enacted 9-23-50): individual income tax rates increased, with increased withholding effective 10-1-50; corporate tax rates increased, applicable to profits in calendar 1950; excise tax rate on gambling devices raised, 10 percent tax extended to television sets and deep-freeze units.

1951 Excess Profits Tax Act of 1950 (enacted 1-3-51): effective 1st quarter 1951 but retroactive to $7-1-50$.

OASDI wage base raised from $\$ 3000$ to $\$ 3600$.

Revenue Act of 1951 lenacted 10-20-51) : individual income tax rates increased, with increased withholding effective 11-1-51; corporate tax rate increased (applicable to profits for 3-31-51) and excess profits credit reduced; excise tax rates raised on distilled spirits, beer, cigarettes, gasoline and automobiles, and a new tax enacted on wagers.

1954 Expiration of Revenue Act of 1951: individual income tax rates reduced.

Excess profits tax allowed to expire.

OASDI tax rate raised from 3.0 percent to 4.0 percent.

Excise 'Tax Reduction Act of 1954 (enacted 331-54): excise tax rates reduced on jewelry, some admissions, telephone service and transportation of persons.

Internal Revenue Code of 1954 lenacted 8 16 . 54): provided for general reform, with liberalzed depreciation allowances one of the most important provisions.

1955

1956

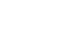

1957 OASDI tax rate raised from 4.0 percent to 4.3 percent.

1958 Excise tax on transportation of property repealed.

1959 OASDI tax rate raised from 4.5 percent to $\mathbf{5 . 0}$ percent, and wage base raised from $\$ 4200$ to $\$ 4800$.

Excise tax rate raised on gasoline.

1960 OASDI tax rate raised from 5.0 percent to 6.0 percent.

Excise tax rate raised on tires, tubes and heavy trucks.

1961 Unemployment insurance tax rate raised from 3.0 percent to 3.1 percent.

1962 OASDI tax rate raised from 6.0 percent to 6.25 percent.

Unemployment insurance tax rate raised from 3.1 percent to 3.5 percent.

Revenue Act of 1962 (enacted 10-16-62): tax credit for investment in equipment allowed.

Depreciation guidelines and rules revised.

1963 OASDI tax rate raised from 6.25 percent to 7.25 percent. 
Unemployment insurance tax rate reduced from 3.5 percent to 3.35 percent.

1964 Unemployment insurance tax rate reduced from 3.35 percent to 3.1 percent.

Revenue Act of 1964 (enacted 2-26-64): individ ual and corporate tax rates reduced, with reduced withholding effective 3-1-64.

1965 Second stage of Revenue Act of 1964.

Excise Tax Reduction Act of 1965 lenacted 621-65): excise tax rates reduced on automobiles and air conditioners (retroactive to $5-15-65$ )

1966 Second stage of Excise Tax Reduction Act of 1965.

OASDI tax rate raised from 7.25 percent to 8.4 percent, and wage base raised from $\$ 4800$ to $\$ 6600$.

Tax Adjustment Act of 1966 (enacted 3-15-66): graduated withholding of individual income taxes introduced effective 5-1-66, and corporate income taxes accelerated the act did not alter tax liabilities).

Investment Credit Suspension Act of 1966 effective 10-10-66.

1967 OASDI tax rate raised from 8.4 percent to 8.8 percent.

Investment tax credit restored, effective 3-9-67 (enacted 6-13-67).

1968 OASDI wage base raised from $\$ 6600$ to $\$ 7800$.

Revenue and Expenditure Control Act of 1968 (enacted 6-28-68): 10 percent individual in come tax surcharge imposed, with withholding effective $7-1-68$ but retroactive to $4-1-68$ (scheduled to expire 6-30-69); 10 percent corporate tax surcharge imposed, applicable to profits in calendar 1968 ischeduled to expire 630-69); scheduled 4-1-68 leduction in the 7 and 10 percent excise tax rates on automobiles and telephone services postponed until January 1970 .

1969 OASDI tax rate raised from 8.8 percent to 9.6 percent.

The 10 percent surcharge, previously scheduled to expire $6-30-69$, extended to 12-31-69.

Tax Reform Act of 1969 lenacted 12-30-69 but generally effective beginning in 1970): personal exemption increased from $\$ 600$ to $\$ 625$ in 1970 , to $\$ 650$ in 1971 , to $\$ 700$ in 1972 and to $\$ 750$ in 1973 ; standard deduction increased from 10 to 15 percent over a three-year period beginning in 1971; maximum marginal rate introduced of 50 percent on earned income (maximum rate on unearned income remained at 70 percent; surcharge extended to $6-30-70$ at a 5 percent rate; scheduled reductions in excise tax rates on automobiles and telephone services postponed until 1-1-71; investment tax credit generally repealed for corporations for property constructed, reconstructed or acquired after 4-18-69

Unemployment insurance tax rate raised from 3.1 percent to 3.2 percent

1970 Surcharge expired on 7-1-70.

Excise, Estate and Gift Tax Adjustment Act of 1970: repeal of excise tax rates on automobiles and telephone services extended to 1-1-72; collection of estate and gift taxes accelerated.

1971 OASDI tax rate raised from 9,6 percent to 10.4 percent.

Treasury's asset depreciation guidelines issued in June 1971) gave firms the option of raising or lowering the "guideline lives" of depreciable assets by up to 20 percent, effective for calendar 1970. (This administrative action was, for the most part, incorporated into legislation as part of the Revenue Act of 1971).

Job development tax credit effective 8-15-71.

Import tax surcharge effective 8-15-71.

Revenue Act of 1971 (enacted 12-10-71): scheduled increases in personal exemptions and the standard deduction accelerated by one year (see Tax Reform Act of 1969); 7 percent excise tax on automobiles repealed retroactive to 8 15-71 and excise tax on small trucks and transit buses repealed retroactive to $9-22-71 ; 7$ percent investment tax credit reinstated.

Elimination of import tax surcharge effective $12-20-71$

1972 OASDI wage base raised from $\$ 7800$ to $\$ 9000$.

Covered wages for unemployment insurance tax raised from $\$ 3000$ to $\$ 4200$.

$\mathbf{1 9 7 3}$ OASDI tax rate raised from 10.4 percent to 11.7 percent, and wage base raised from $\$ 9,000$ to $\$ 10,800$. 
Unemployment insurance tax rate raised from 3.2 percent to 3.28 percent.

1974 OASDI wage base raised from $\$ 10,800$ to $\$ 13,200$.

Unemployment insurance tax rate reduced from 3.28 percent to 3.2 percent.

1975 OASDI wage base raised from $\$ 13,200$ to $\$ 14,100$.

Import fees on petroleum products increased $\$ 1$ per barrel on 2-1-75.

Tax Reduction Act of 1975 (enacted 3-29-75): generally effective retroactive to $1-1-75$; individual income taxes reduced including a $\$ 8.1$ bilm lion rebate on 1974 income and with lower withholding ates effective 5-1-75 reflecting increases in the minimum and standard deductions and a $\$ 30$ credit against taxes paid on 1975 income; investment tax credit increased from 7 percent 14 percent for utilities) to 10 percent for property acquired between 1-21-75 and 1-1-77; corporate surtax exemption increased from $\$ 25,000$ to $\$ 50,000$ and rate on first $\$ 25,000$ reduced from 22 to 20 percent; oil depletion allowance repealed and limits placed on corporate use of foreign tax credits and deferral.

Import fees increased $\$ 1$ per barrel on petroleum products on 6-1-75.

Revenue Adjustment Act of 1975; ongoing provisions of the Tax Reduction Act of 1975 essentially extended, except for the tax rebate.

1976 OASDI wage base raised from $\$ 14,100$ to $\$ 15,300$

Tax Reform Act of 1976 lenacted 10-4-76: individual income provisions of the Revenue Adjustment Act of 1975 essentially extended in. cluding extending the per capita tax credit and the refundable eamed income credit, making permanent the standard deduction of $\$ 2,400$ for single returns and $\$ 12,800$ for joint retums: estate tax exemption raised; the corporate income provisions of the Revenue Adjustment Act of 1975 extended, including reduction in corporate tax rates extension of surtax exemption of $\$ 50,000$ through 1977 and extension of the investment tax cadit through 1980.

1977 OASDI wage base raised from $\$ 15,300$ to $\$ 16,500$.
Unemployment insurance tax raised from 3.2 percent to 3.4 percent.

Excise tax on telephone service reduced.

Tax Reduction and Simplification Act lenacted 5-23-77): effective $6-1-77$, standard deduction modiffed, reducing withholding; jobs tax credit for corporations enacted.

$\mathbf{1 9 7 8}$ OASDI tax rate raised from 11.7 percent to 12.1 percent and wage base raised from $\$ 16,500$ to $\$ 17,700$.

Covered wages for unemployment insurance tax raised from $\$ 4,200$ to $\$ 6,000$.

Excise tax on telephone service reduced.

Revenue Act of 1978 lenacted 11-6-78): effective 1-1-79; personal exemption increased from $\$ 750$ to $\$ 1,000$, replacing the temporary general tax credit; tax brackets indexed, tax rates cut and zero bracket amount increased; earned income credit increased and deductions for state and local fuel taxes repealed; corporate tax rates reduced; broadened and made permanent the investment tax credit at 10 percent; jobs tax credit modified.

Energy Tax Act of 1978 lenacted 11-9-78): lax credits allowed for energy-conserving expenditures retroactive to $4-20-77$.

Foreign Earned Income Act of 1978 (enacted 10-15-78): tax laws blyeralized for U.S. citizens living abroad.

1979 OASDI tax rate raised from 12,1 percent to 12.26 percent and wage base raised from $\$ 17,700$ to $\$ 22,900$.

Excise tax on telephone service reduced.

1980 OASDI wage base raised from $\$ 22,900$ to $\$ 25,900$.

Crude Oi Windfall Profit Tax Act of 1980 enacted $4-2-80)$ : retroactive to $3-1-80$; comporate fax reduced because of deductibility of windfall profis tax which is an excise tax; excise tax on telephone service reduced; temporary fee of $\$ 4.62$ per barrel placed on imported crude oil effective $3-15-80$.

Omnibus Reconciliation Act of 1980: effective 1 1-81: use of tax-exempt mortgage subsidy bonds restricted for individuals and corporations. 
1981 OASDI tax rate raised from 12.26 percent to 13.3 percent and wage base raised from 525,900 to $\$ 29,700$.

Economic Recovery Tax Act of 1981 lenacted 813-81): cost recovery system accelerated for corporations, applicable to 1981 income; credit for the windfall profits tax increased for corporations; individual income tax rates reduced 25 percent over 33 months with the first stage a 5 percent cut on 10-1-81.

1982 OASDI tax rate rased from 13.3 percent to 13.4 percent and wage base raised from $\$ 29,700$ to $\$ 32,400$.

Economic Recovery Tax Act: tax rates reduced on income not subject to withholding and exclusion from gross income of interest and dividends repealed; estate and gift taxes reduced.

Tax Equity and Fiscal Responsibility Act of 1982 (enacted $9-3+82$ !: modified coinsurance transactions repealed effective 1-1-82; vatious modifications and restrictions for leasing enacted, generally effective $7-1-82$; airport and airway taxes increased eflective 9-1-82

Economic Recovery Tax Act of 1981: second stage of tax reduction, 10 percent on $7-1-82$.

1983 OASDI wage base raised from $\$ 32,400$ to $\$ 35,700$.

Unemployment insurance tax raised from 3.4 to 3.5 percent, and covered wages raised from $\$ 6,000$ to $\$ 7,000$.

Tax Equity and Fiscal Responsibility Act of 1982: compliance provisions of individual income tax strengthened and casualty and medical expense deductions modified; basis for investment tax credit for corporations adjusted and contract method of accounting modified; cigarente tax doubled to 16 cents per pack on 1 1-83 and excise tax increased on telephone service from 1 percent to 3 percent

Highway Revenue Act of 1982 (enacted $1-5-83$ ): tax on gasoline and diesel fuel increased from 4 to 9 cents per gallon effective 4-1-83; general taxes repealed on tires, lublicating oil, and retail sales of lightweight trucks and trailers; taxes increased on heary-duly trucks and trailers.

Social Security Amendments of 1983 lenacted April 1983: previously scheduled tax rate increase accelerated; cmployee share of the rate increase in 1984 reduced by 0.3 percentagepoint; self-employed tax rate increased; coverage of new federal civilian employees and employees of nomprofit organizations made mandatory; taxation of social security benefits required when income exceeds certain levels.

Economic Recovery Tax Act of 1981: third stage of tax reduction, 10 percent on 7-1-83.

Railroad Retirement Revenue Act of 1983 tenacted August 1983): changes similar to Social Security Amendments introduced.

1984 OASDI tax rate raised from 13.4 percent to 14.0 percent, and wage base raised from $\$ 35,700$ to $\$ 37,800$.

Deficit Reduction Act of 1984 (enacted $7-18-84$ ): tax-exempt entity leasing restricted; depreciation period for real property lengthened; taxation of life insurance companies modifed; interest exclusion as allowed for under Economic Recovery Tax Act of 1981 repealed; income averaging modified.

1985 OASDI tax rate raised from 14.0 percent to 14.1 percent, and wage base raised from $\$ 37,800$ to $\$ 39,600$.

Unemployment insurance tax raised from 3.5 to 6.2 percent.

Economic Recovery Tax Act of 1981: indexing of individual income tax began.

Tax Equity and Fiscal Responsibility Act of 1982: accelerated depreciation schedules for 1985 to 1986 under the Economic Recovery $\mathrm{Tax}$ Act of 1981 repealed.

Deficit Reduction Act of 1984: alcohol tax in creased from $\$ 10.50$ to $\$ 12.50$ per proof gallon effective $10-1-85$.

1986 OASDI wage base raised from $\$ 39,600$ to $\$ 42,000$.

Consolidated Omnibus Budget Reconciliation Act of 1985 lenacted 4-7-861: excise tax on coal production increased; medicare coverage extended to new state and local employees.

Tax Peform Act of 1986 lenacted 10-22-86! : federal lax system overhauled by broadening the individual and corporate tax bases and lowering individual and comporate tax rates; generaly effective 1-1-87 except for repeal of inves $1-$ ment tax credit effective 1-1-86 and transition to modified depreciation schedules effective Cor $^{2}$ property placed in semice after $7-31-86$. 